\title{
The Effect of Emotional Freedom Technique Therapy on Nurse Burnout
}

\author{
Ni Made Nopita Wati*, Ni Wayan Mirayanti **, I Gede Juanamasta *** \\ *M Author Correspondence: ners.pita@gmail.com \\ *STIKes Wira Medika Bali, Denpasar, Indonesia \\ **STIKes Wira Medika Bali, Denpasar, Indonesia \\ ***STIKes Wira Medika Bali, Denpasar, Indonesia
}

\begin{tabular}{l}
\hline I N D E X I N G \\
\hline Keywords: \\
Burnout; \\
Emotional Freedom \\
Technique; \\
Nurse;
\end{tabular}
\begin{abstract}
A B S T R AC T
Burnout can develop as a result of long work stress and cause a change in attitudes and behaviors withdrawing psychologically. The most visible impact of burnout is the decline in performance and quality of service. As a result, they were unable to fulfill the work demands and finally decided not to attend, increasing rates of sick leave, reduced work effectiveness or even leaving their jobs. This study aims to determine the effect of Emotional Freedom Technique (EFT) therapy on burnout in implementing nurses. The design of this study uses quasi-experimental design with control group. The sample in the study were 38 nurses, divided into 2 groups, each group consisting of 19 people selected through purposive sampling. This study used the Wilcoxon Signed Rank Test to determine the differences in one pre-post group and the Mann Whitney Test to analyze changes after two different post-post groups. The results showed the value of $p$ value in the treatment group $=0,000$ which means that there was an effect of therapy (EFT) on burnout in the implementing nurses, whereas in the control group there was no difference with the $p$ value $=0.925$, the $p$ value was influenced by EFT therapy (Emotional Freedom Technique ) towards burnout of nurse nurses before and after in groups of 0,000 . It is expected that the Hospital can overcome burnout by passing EFT therapy.
\end{abstract}

Kata kunci:
Burnout;
Emotional Freedom
Technique;
Perawat;

\begin{abstract}
Burnout dapat berkembang sebagai akibat dari stres kerja yang lama dan mengakibatkan suatu perubahan sikap dan perilaku menarik diri secara psikologis. Dampak yang paling terlihat dari burnout adalah menurunnya kinerja dan kualitas pelayanan. Akibatnya, mereka tidak dapat memenuhi tuntutan pekerjaan dan akhirnya memutuskan untuk tidak hadir, peningkatan angka cuti sakit, efektivitas kerja berkurang atau bahkan meninggalkan pekerjaannya. Penelitian ini bertujuan untuk mengetahui Pengaruh terapi Emotional Freedom Technique (EFT) terhadap burnout pada perawat pelaksana. Desain penelitian ini menggunakan quasi-experimental design with control group. Sampel dalam penelitian sebanyak 38 orang perawat, terbagi menjadi 2 kelompok, masingmasing kelompok terdiri dari 19 orang dipilih melalui purposive sampling. Penelitian ini menggunakan Uji Wilxocon Signed Rank untuk mengetahui perbedaan pada satu kelompok pre-post dan Uji Mann Whitney untuk menganalisis perubahan sesudah pada dua kelompok yang berbeda post-post. Hasil penelitian menunjukkan nilai $p$ value pada kelompok perlakuan $=0,000$ yang artinya ada pengaruh terapi (EFT) terhadap burnout pada perawat pelaksana, sedangkan pada kelompok kontrol tidak ada perbedaan dengan nilai $p$ value $=0,925$, nilai $p$ value ada pengaruh terapi EFT (Emotional Freedom Technique) terhadap burnout perawat pelaksana sebelum dan sesudah pada kelompok sebesar 0,000. Diharapkan agar pihak Rumah Sakit dapat mengatasi burnout dengan melalukan terapi EFT.
\end{abstract}

(C) 2019 JMMR. All rights reserved

Article History: Received 2019-Nov-11; Revised 2019-Dec-20; Accepted 2019-Dec-23

\section{INTRODUCTION}

Nurses as health workers who work for 24 hours must always provide maximum care in their services. In fact, not all nurses are able to carry out their duties and functions properly; often they experience mental and emotional exhaustion, due to the task and the fact that they must always be ready to provide good service for people. This will be able to deplete the nurses' stamina and emotions, as well as cause pressure which results in nurses experiencing burnout. ${ }^{-}$Burnout is a work-related syndrome characterized by excessive fatigue, 
cynicism and decreased professional efficacy. Fatigue is felt not only physically, but also mentally and emotionally.

Burnout can develop as a result of prolonged work stress. This syndrome consists of three dimensions, namely emotional exhaustion, depersonalization and low selfesteem. Fatigue in this case is characterized by the depletion of emotional resources so that an individual experiences suffering and feels overwhelmed, emotions are drained away. ${ }^{-}$

The results of research in the UK show that $42 \%$ of nurses experienced burnout, in Greece around $44 \%$ of nurses felt dissatisfaction at work. Nurses working in large hospitals in southern Brazil showed that the prevalence of nurses experienced burnout is $35.7 \%$. Research in Arab shows that nurses experience a burnout dimension, namely, $45.6 \%$ of nurses experiencing emotional exhaustion, $42 \%$ experiencing depersonalization, and $28.5 \%$ experiencing low self-esteem. ${ }^{4}$

Research conducted in Germany shows that $8 \%$ of workers experiencing work stress for 30 days has an impact not only on the workplace but also on the personal lives of workers, such as deteriorating conditions in the family and friendships..$^{-}$The results of research in Spain and the Netherlands show that $1.89 \%$ to $2.84 \%$ of nurses experienced burnout; based on the above presentation it can be seen that as a profession nurses experienced the most burnout. According to Kleiber \& Ensman ${ }^{-1}$ with regard to burnout in Europe, their research shows that $43 \%$ burnout is experienced by health and social workers (nurses).

The most visible impact of burnout is a decrease in performance and service quality. Individuals who experience burnout will lose the meaning of the work they do because of the prolonged response to the emotional, physical and mental fatigue they experience. As a result, they are unable to meet the demands of work, and ultimately decide not to attend; an increase in sick leave, reduced work effectiveness or even leaving work. ${ }^{6}$

Some treatments to overcome burnout have been done multiple times but the results have not been maximized. The current therapy being developed is Emotional Freedom Technique (EFT) therapy which is a concept of ancient Chinese medicine and healing culture, adopted from the needling or acupuncture method. ${ }^{7}$ This therapy can overcome a variety of physical complaints, this is proven through various studies that have an influence in lowering blood pressure in people with hypertension.

\section{RESEARCH METHOD}

The research design is quantitative using the Quasi Experiment Pre and Post with Control Group Design research design. This research was conducted at Hospital Wangaya Denpasar. The room used is the internal medicine room, the Cendrawasih room for the intervention group and the Belibis room for the Control group. This research was conducted on March 25 - April 8, 2019. The population in this study were all nurses in the inpatient wards at Wangaya Hospital totaling 242 people. The sample selection was done by Purposive Sampling that is chosen through the determination of inclusion and exclusion criteria. Data collection techniques were done with nurse burnout questionnaire sheets. The samples are 38 respondents including the treatment and control groups.

\section{RESULTS AND DISCUSSION}

The sample of this study was nurses who experienced burnout at the Wangaya Hospital in Denpasar who are unable to fulfill job guidelines and decided not to attend their work, an increase in the number of sick leave and even totally leaving work. With the sample selection, in accordance with the study criteria,, it is obtained a sample of 38 respondents who met the inclusion criteria, of the 38 respondents they were divided into 2 groups: the treatment group and the control group.

Table 1. Characteristics of respondents

\begin{tabular}{|c|c|c|c|c|c|}
\hline \multirow[t]{4}{*}{ No } & \multirow[t]{4}{*}{ Variable } & \multicolumn{4}{|c|}{ Group } \\
\hline & & \multicolumn{4}{|c|}{ Intervention $(\mathbf{N}=$ Control $(\mathbf{N}=$} \\
\hline & & \multicolumn{2}{|c|}{ 23) } & \multicolumn{2}{|c|}{ 23) } \\
\hline & & $\mathbf{F}$ & $\%$ & $\mathbf{F}$ & $\%$ \\
\hline 1. & Age & & & & \\
\hline & a. 20-30 years & 14 & 73.7 & 8 & 42.1 \\
\hline & b. $31-40$ years & 5 & 26.3 & 9 & 47.4 \\
\hline & c. $>40$ years & - & - & 2 & 10.5 \\
\hline 2. & Gender & & & & \\
\hline & a. Male & 3 & 15.8 & 7 & 36.8 \\
\hline & b. Female & 16 & 84.2 & 12 & 63.2 \\
\hline 3. & Education Level & & & & \\
\hline & a. DIII Nursing & 13 & 68.4 & 12 & 63.2 \\
\hline & b. Nursing & 6 & 31.6 & 7 & 36.8 \\
\hline 4. & Marital Status & & & & \\
\hline & a. Unmarried & 4 & 21.1 & 1 & 5.3 \\
\hline & b. Married & 15 & 78.9 & 18 & 94.7 \\
\hline 5. & Work Period & & & & \\
\hline & a. $>1$ year & 7 & 36.8 & 4 & 21.1 \\
\hline & b. $5-10$ years & 9 & 47.4 & 8 & 42.2 \\
\hline & c. $11-20$ years & 3 & 15.8 & 6 & 31.6 \\
\hline & d. $>20$ years & - & - & 1 & 5.3 \\
\hline
\end{tabular}


Table 1. show that the majority, 14 people (73.7\%), of respondents in the intervention group were in the age of 20-30 years old while in the control group 9 people (47.4\%) were in the age of 31-40 years old. Most of the respondents' genders in the intervention and control groups were women, that is, as many as 16 people $(84.2 \%)$ in the intervention group and as many as 12 people $(63.2 \%)$ in the control group. With regard to the education level of respondents, in the intervention group, 13 people (68.4\%) were graduated from DIII Nursing and in control group 12 people $(63.2 \%)$ were graduated from DIII Nursing. The marital status of the majority of respondents in the intervention and control groups was married, namely 15 people (78.9) in the intervention group and 18 people (94.7\%) in the control group. The majority of respondents in the intervention and control group had a working period of 5-10 years, with as many as 9 people $(47.4 \%)$ in the intervention group and as many as 8 people $(42.1 \%)$ in the control group.

Table 2. Pre-test and Post-test Observation Results of the Intervention Group in the Cendrawasih Room

\begin{tabular}{ccccc}
\hline \multirow{2}{*}{ Nurses Burnout } & \multicolumn{3}{c}{ Intervention Group } \\
& Nre-test & \% & N & Post-test \\
\hline Low 47-70 & 3 & 15.8 & 19 & 100 \\
High 71-92 & 16 & 84.2 & 0 & 0 \\
Total & 19 & 100 & 19 & 100 \\
\hline
\end{tabular}

The results showed that most nurses, 14 people (73.7\%), aged 20-30 years experienced burnout. The results of this study are in line with the results of Sari's research (8) which states 12 (34.3\%) nurses aged 20-30 years old experience burnout. According to Farber's theory ${ }^{8}$ which states $12(34.3 \%)$ nurses aged 20-30 years old experience burnout. According to Farber's theory the highest level of burnout occurs in nurses with a relatively younger age. Researchers concluded that nurses with young age are more prone to burnout, because nurses at this age still need a process to adapt to their work environment, in this process; nurses will be susceptible to burnout. ${ }^{-}$

The results showed that most female nurses, 16 people (84.2\%), experienced burnout of. The results of this research are inversely proportional to the results of research by $\mathrm{Wati}^{9}$, which states that men are more prone to burnout, this is influenced by the distribution of the number of male nurses who are more than the female counterpart. According to Farber's theory the highest level of burnout occurs in female nurses. Researchers assume because the number of female nurses is less than male nurses. ${ }^{1}$
The results showed that most nurses, 13 people (68.4\%), with DIII Nursing education experienced burnout. The results of this study are in line with the results of Sari's study where DIII-educated nurses are more prone to burnout. According to Farber's theory the higher the level of education of nurses, the lower the level of burnout would be. ${ }^{1,8}$ Researchers assume that this is due to the fact that the number of nurses with DIII Nursing education is less than the nurses with Bachelor of Nursing education. Therefore researchers can conclude, the higher the level of education of nurses, the less nurses would experience burnout.

The results showed that the majority of nurses, 9 people (47.4\%), who had a working period of 5-10 years, experience burnout. The results of this study are in line with the results of Wati's research which states that the length of service influences the burnout of nurses, where most of the nurses have relatively less tenure (more than five years and less than ten years). ${ }^{-}$According to Farber's theory the higher the work experience is, the lower the level of burnout would be, otherwise the lesser the work experience is, the higher the level of burnout would be. Researchers suggest that, the length of service affects the burnout level of nurses, perhaps due to pressure from seniors, and due to the fact that they do not have strong attachments to the work.

The results showed that most nurses, 15 people (78.9\%), with married status experienced burnout. The results of this study are inversely proportional to the results of the study of Whitehead, who suggests that the higher burnout is experienced by unmarried nurses. $\frac{10}{}$ Unmarried people do not have a good support system, thus they are vulnerable to burnout. According to Farber's theory unmarried individuals are reported to be more susceptible to burnout syndrome compared to married individuals. ${ }^{1}$ Researchers assume that in this study nurses who are married had more responsibility therefore nurses with married status were more prone to burnout.

The results showed that 16 nurses $(84.2 \%)$, before being given EFT therapy, experienced a high burnout, whereas after being given EFT therapy all respondents, 19 people $(100 \%)$, experienced a low burnout. The results of this study are in line with Wati's research showing that before caring leadership was applied to the intervention group, the result was 67.61, whereas after caring leadership was applied, the result was $66.17 .^{9}$

There is a change in the level of burnout in nurses after being given EFT therapy due to a combination of techniques that support the effectiveness of EFT therapy. 
The affirmation sentences done at the set-up time can reduce individual problems, fatigue, stress, anxiety and can improve self-control. ${ }^{11}$ Tune-in techniques in EFT to focus the mind on anxiety, stress experienced at the moment. In this condition mindfulness is accompanied by selfacceptance of events or problems experienced and thus can reduce fatigue. $\frac{12}{}$ Mild tapping that is done to overcome psychological disorders can provide biochemical effects in the form of identification of neurotransmitters, endorphins, and other chemicals in the brain, so that it can reduce fatigue.

Table 3. Pre-test and Post-test Observation Results of the Control Group in the Belibis Room

\begin{tabular}{ccccc}
\hline \multirow{2}{*}{ Nurses Burnout } & \multicolumn{4}{c}{ Control Group } \\
& N & \% & N & \% \\
\hline Low 47-70 & 2 & 10.5 & 4 & 21 \\
High 71-92 & 17 & 89.5 & 15 & 79 \\
Total & 19 & 100 & 19 & 100 \\
\hline
\end{tabular}

The results showed that most nurses aged 31-40 years old, 9 people $(47.4 \%)$, experienced burnout. The results of this study are inversely proportional to the results of Shimizu's research which states that young age shows a higher burnout rate. $\frac{13}{-}$ According to Maslach's theory, younger employees experience higher burnout than employees older than 30 or 40 years old, because age is defined as work experience so that burnout appears as an early risk of one's career. Researchers assume that the number of nurses in late adulthood is more than the young age.

The results showed that most female nurses, 12 people $(63.2 \%)$, experienced burnout. The results of this research are inversely proportional to the results of research Sulistyowati which states that male nurses are more susceptible to burnout when compared to female nurses. $\frac{14}{4}$ According to Maslach's theory, women tend to experience emotional exhaustion. Researchers assume that this is the fact because the number of female nurses is less than male nurses.

The results showed that most nurses, 12 people (63.2\%), with DIII Nursing education experienced burnout. The results of this research are in line with the results of Adjeng's research where nurses with DIII education are more prone to burnout. According to the theory of Maslach and Jakson the level of education also influences burnout. $\frac{815}{}$ This is based on the fact that stress related to work problems is often experienced by workers with low education. Researchers can conclude, the higher the level of education of nurses, the less burnout would the nurse experience.

The results showed that the majority of nurses, 8 people $(42 \%)$, who had a working period of 5-10 years experienced burnout. The results of this study are in line with the results of Patrrick's study which states that years of service have an influence on nurse burnout. $\frac{16}{-}$ People who work with less experience are more prone to experiencing burnout, where the more experienced someone in a job, the more ability they would have to deal with the situation at work, therefore that active and experienced nurses will be better able to deal with stress at work which can cause burnout to nurse..$^{17}$ The researchers conclude that the working period affects the nurses' burnout, the less work experience the nurses have, the more susceptible the nurses are to experience burnout.

The results showed that most married nurses, 18 people $(94.7 \%)$, experienced burnout. The results of this study are inversely proportional to the results of Farber's study which states that marital status influences burnout. ${ }^{18}$ People who are not married are more prone to burnout than people who are married. According to Farber's theory unmarried individuals are reported to be more susceptible to burnout syndrome compared to married individuals. ${ }^{1}$ Researchers assume that in this study nurses who are married had more responsibility, thus married nurses were more prone to burnout.

The results showed that before being given EFT therapy, respondents, 17 nurses (89.5\%), experienced a high burnout, while the same thing happened at the time of the post-test where most respondents, 15 people $(79 \%)$, experienced high burnout. The results of this study are in line with Wati's research showing that before caring leadership was applied in the control group, the result was 67.39, whereas after caring leadership was applied, the result was $67.87 .{ }^{-}$

Table 4. Results of the Pre and Post-Test Analysis of the Intervention Group in the Cendrawasih Room and the Control Group in the Belibis Room in the Wangaya Hospital Denpasar

\begin{tabular}{cccc}
\hline Variable & Group & $\begin{array}{c}\text { P value } \\
\text { Wilcoxon } \\
\text { Signed Rank }\end{array}$ & $\begin{array}{c}\text { P value } \\
\text { Mann } \\
\text { Whitney }\end{array}$ \\
\hline Burnout & $\begin{array}{c}\text { Intervention } \\
\text { Control }\end{array}$ & 0.000 & 0.000 \\
& 0.925 & \\
\hline
\end{tabular}


The results showed that the $\mathrm{p}$ value for the intervention group and the control group are 0,000 . The results of this study are in line with the results of Wati's research The Implementation of Caring Leadership of the Head of Room on the Nurse Burnout with a $p$ value of 0,000 . The control group that was not given intervention still showed burnout. ${ }^{-}$

Emotional Freedom Technique (EFT) is a practical psychological therapy that can deal with many diseases, both physical and psychological illnesses, namely problems of mind and feelings. ${ }^{7}$ In the research conducted at the Wangaya Hospital Denpasar, the EFT therapy was carried out for 3 cycles with less than 10 minutes and it took 2 weeks to provide this therapy. Based on the results of the analysis of the administration of EFT therapy to burnout experienced by the nurses in the intervention group with $\alpha$ $=0.05$, a $\mathrm{p}$ value of 0.000 was obtained, because the value of $\mathrm{p}<\boldsymbol{\alpha}$, it was concluded that there was an effect of emotional freedom technique (EFT) therapy on burnout of the nurses.

Some of the results of researchers about the effectiveness of EFT administration; according to Rajin $\stackrel{18}{=}$, Spiritual Emotional Freedom Technique (SEFT) Therapy to Improve Sleep Quality of Postoperative Patients in the Hospital which was carried out for 5 minutes, once a day and carried out for 3 consecutive days. The statistical analysis used was the Anova test with a significance of P $\leq$ 0.05 . One way Anova statistical test results on the first day obtained the value of $\mathrm{P}=0.009$ and on the third day the value of $\mathrm{P}=0.000$. Based on the results of this study it can be concluded that SEFT therapy can significantly improve the patient's sleep quality.

According to Lutfatul Latifah the administration of EFT Therapeutic Interventions to Reduce Postoperative Pain of Sectio Caesaria (SC) which was performed for 30 minutes on the first day and 30 minutes were given for three cycles of therapy from the set-up, sequence 1, gammut procedure, and sequence 2 . The results of the average pain scale before the intervention in the control group was 5.20 and in the intervention group was 6.20 . The average pain scale after the intervention in the control group was 5.00 and in the intervention group it was 4.27. $\frac{19}{}$ There was a significant difference in the decrease in pain scale between before and after the intervention in the intervention group with $p$ value $=0,000(\alpha=0.05)$.

Lane's research which shows that manually stimulating the acupoints can regulate cortisol, reduce pain by producing endorphin hormones, slowing the heart rate, reducing fatigue, regulating the autonomic nervous system and creating a sense of calm. Subjects also felt that while doing EFT, the stress hormones that initially increased, namely, cortisol, epinephrine, and norepinephrine which were released by the adrenal glands were decreasing after EFT accompanied by the release of endorphin hormones, thus that subjects who did EFT would feel calmer, more comfortable and relaxed after doing EFT. ${ }^{20}$

The researcher is of the opinion that there is a change in the level of burnout in the nurses after being given EFT therapy due to a combination of techniques that support the effectiveness of EFT therapy. The affirmation sentences done at the set-up time can reduce individual problems, fatigue, stress, anxiety and can improve self-control. Tunein techniques in EFT to focus the mind on anxiety, stress experienced at the moment. In this mindfulness condition, it is also accompanied by self-acceptance of events or problems experienced and can reduce fatigue. Mild tapping that is done to overcome psychological disorders can provide biochemical effects in the form of identification of neurotransmitters, endorphins, and other chemicals in the brain, so that it can reduce fatigue. For an effective EFT therapy so that there are changes, in this study was done in 3 cycles with less than 10 minutes for 2 weeks.

\section{CONCLUSION}

Based on the results of research conducted on burnout of nurses at Wangaya Hospital Denpasar and from the results of the discussion, it can be concluded that: Before being given EFT therapy the majority of respondents, 16 nurses $(84.2 \%)$, experienced a high burnout while after being given therapy all nurses,19 nurses (100\%), experienced a low burnout. Before being given EFT therapy, most of the respondents, 17 people (89.5\%), experienced high burnout. The same thing happened at the post-test where most respondents, 15 people (79\%), experienced a high burnout. There was a difference in the intervention group and the control group with a $\mathrm{p}$ value of 0,000 in the intervention group while in the control group there was no difference with the $p$ value of 0.925 . There is an effect of EFT (Emotional Freedom Technique) therapy on the burnout of nurses before and after in the intervention group with $\alpha=0.05$, and the $p$ value is 0.000 .

Researchers suggest to the Hospital, the Hospital Management to carry out EFT therapy exercises for nurses who have burnout that have been controlled in order to maintain their conditions to remain stable, and to reduce fatigue. Nurses are expected, if the condition of burnout is controlled, to do EFT therapy exercises regularly so that the 
burnout experienced can be controlled. To other researchers, when conducting research on nurses who experience burnout are expected to increase the number of variables and add characteristics of staffing status, so that the results of research on burnout become more extensive and comprehensive.

\section{REFERENCE}

1. Prestiana NDI, Purbandini D. Hubungan antara efikasi diri (self efficacy) dan stres kerja dengan kejenuhan kerja (burnout) pada perawat IGD dan ICU RSUD Kota Bekasi. SOUL J Ilm Psikol. 2012;5(2):1-14.

2. Enzmann D. The burnout companion to study and practice: A critical analysis. Taylor \& Francis; 1998.

3. Maslach, C. Scaufeli, WB LM. Job Burnout. 2001;397-422.

4. Tampubolon LF. Burnout Syndrome Pada Perawat Di Ruangan Rawat Inap Rumah Sakit Santa Elisabeth Medan. J Keperawatan Prior. 2018;1(1).

5. Nink M. The German Work Force Has a Burnout Problem. Bussiness J. 2015;

6. Nursalam. Metodologi Penelitian Ilmu Keperawatan Pendekatan Praktis. 4th ed. Jakarta: Salemba; 2015.

7. Dewi NLPT, Arifin MT, Suhartini S. Pengaruh Gayatri Mantra dan Emotional Freedom Technique (EFT) terhadap Quality of Life Pasien Pasca Stroke. Diponegoro University; 2018.

8. Sari DY. Hubungan beban Kerja, faktor demografi, locus of control dan harga diri terhadap burnout syndrome pada perawat pelaksana IRD RSUP Sanglah. COPING (Community Publ Nursing). 2015;3(2).

9. Wati NMN, Ardani H, Dwiantoro L. Implementation of Caring Leadership Model Had an Effect on Nurse's Burnout. J Ners dan Kebidanan Indones. 2018;5(3):165-73.

10. Patterson SL. The effect of emotional freedom technique on stress and anxiety in nursing students: A pilot study. Nurse Educ Today. 2016;40:104-10.

11. Rancour P. The Emotional Freedom Technique: Finally, a Unifying Theory for the Practice of Holistic Nursing, or Too Good to Be True? J Holist Nurs. 2017;35(4):382-8.

12. Shimizu T, Mizoue T, Kubota S, Mishima N, Nagata S. Relationship between burnout and communication skill training among Japanese hospital nurses: a pilot study. J Occup Health. 2003;45(3):185-90.

13. Sulistyowati P. Hubungan antara Burnout dengan Self Efficacy pada Perawat Di Ruang Rawat Inap RSUD
Prof. Dr. Margono Soekarjo Purwokerto. J Keperawatan Soedirman. 2007;2(3):162-7.

14. Adawiyah RAR. Kecerdasan Emosional, Dukungan Sosial dan Kecenderungan Burnout. Pers J Psikol Indones. 2013;2(2).

15. Patrick K, Lavery JF. Burnout in nursing. Aust J Adv Nurs. 2007;24(3):43.

16. Wati NMN. "Abc's Stress Management": Upaya Menurunkan Burnout Berfokus Pada Individu. Adi Husada Nurs J. 2017;3(1):33-8.

17. Farber B. Crisis in education : Stres Management. Vol. 7. In New York. America; 1991.

18. Rajin M. Terapi Spiritual Emotional Freedom Tehnique (SEFT) Untuk Meningkatkan Kualitas Tidur Pasien Pasca Operasi di Rumah sakit. Pros Semin. 2012;1(2).

19. Latifah L, Ramawati D. Intervensi Emotional Freedom Technique (Eft) Untuk Mengurangi Nyeri Post Operasi Sectio Caesaria (Sc). Indones Nurs J Educ Clin. 2018;1(1):53-60.

20. Lane J. The neurochemistry of counterconditioning: Acupressure desensitization in psychotherapy. Energy Psychol Theory, Res Treat. 2009;1(1):31-44. 